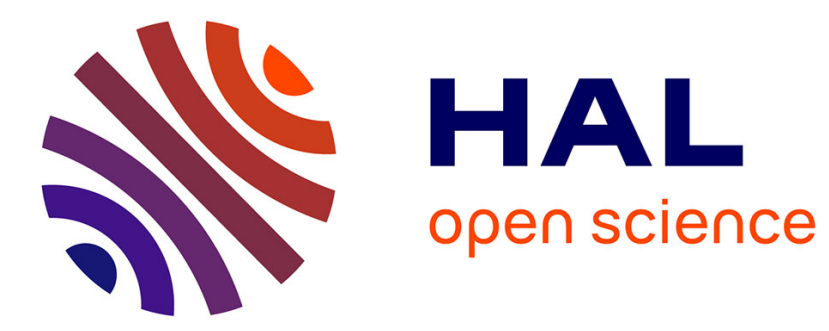

\title{
Pt LIII-Edge EXAFS Studies on Pt-Cu-Fe Alloy Electrocatalysts Supported on Carbon
}

D.-K. Kim, J.-H. Choy, K.-S. Han, S.-J. Hwang, W. Roh, H. Kim

\section{To cite this version:}

D.-K. Kim, J.-H. Choy, K.-S. Han, S.-J. Hwang, W. Roh, et al.. Pt LIII-Edge EXAFS Studies on Pt-Cu-Fe Alloy Electrocatalysts Supported on Carbon. Journal de Physique IV Proceedings, 1997, 7 (C2), pp.C2-953-C2-954. 10.1051/jp4:1997298 • jpa-00255372

\section{HAL Id: jpa-00255372 https://hal.science/jpa-00255372}

Submitted on 1 Jan 1997

HAL is a multi-disciplinary open access archive for the deposit and dissemination of scientific research documents, whether they are published or not. The documents may come from teaching and research institutions in France or abroad, or from public or private research centers.
L'archive ouverte pluridisciplinaire HAL, est destinée au dépôt et à la diffusion de documents scientifiques de niveau recherche, publiés ou non, émanant des établissements d'enseignement et de recherche français ou étrangers, des laboratoires publics ou privés. 


\title{
Pt L LII-Edge EXAFS Studies on Pt-Cu-Fe Alloy Electrocatalysts Supported on Carbon
}

\author{
D.-K. Kim, J.-H. Choy*, K.-S. Han**, S.-J. Hwang*, W. Roh* and H. Kim* \\ Department of Chemistry, Kyungpook National University, Taegu 702-701, Korea \\ * Department of Chemistry, Center for Molecular Catalysis, Seoul National University, Seoul 151-742 \\ Korea \\ ** Inorganic Chemistry Division, National Institute of Technology and Quality, Kyunggi-do 427-010, \\ Korea
}

\begin{abstract}
Carbon supported Pt-Cu-Fe alloys with compositions of $\mathrm{Pt}: \mathrm{Cu}: \mathrm{Fe}=6: 1: 1$ and 2:1:1 have been prepared. Both catalysts exhibit higher specific activities for oxygen reduction than $\mathrm{Pt}$ alone. In order to reveal the local structure around Pt, we have performed X-ray absorption experiment at the $\mathrm{Pt} \mathrm{L}_{\mathrm{m}}$-edge. The local structure around $\mathrm{Pt}$ has been analyzed by fitting the first shell including the Pt-Pt, Pt-Cu, and Pt-Fe contributions to EXAFS spectra. The fitted C.N. for both alloys are similar to that for bulk $\mathrm{Pt}$, indicating that the particle size is not small. The Pt-Pt distances for both alloys are found to be slightly shorter than that of bulk Pt, and the Pt-Cu and Pt-Fe distances decrease as the amounts of $\mathrm{Cu}$ and $\mathrm{Fe}$ increase. It is therefore concluded that the catalytic activity is strongly influenced by the bonding character.
\end{abstract}

\section{INTRODUCTION}

Highly dispersed platinum on carbon supports is well-known electrocatalyst for oxygen cathode in low temperature fuel cells such as phosphoric acid or polymer electrolyte fuel cells. Alloying supported platinum with one or several transition metals has improved the electrochemical activity for oxygen reduction reaction. Several investigators [1] have studied the alloying effect, but there still remains debate on the reason of enhanced activity. In this study, we prepared carbon supported Pt-Cu-Fe ternary alloy electrocatalysts with two compositions of $\mathrm{Pt}: \mathrm{Cu}: \mathrm{Fe}=6: 1: 1$ and 2:1:1 that are useful for oxygen cathode in low temperature fuel cells. We have investigated the local structure of those supported metal clusters by means of the extended Xray absorption fine structure (EXAFS) spectroscopy. The application of EXAFS to such a highly dispersed material can give us information on the local structure, which otherwise can be hardly obtained.

\section{EXPERIMENTAL}

Alloy catalysts were prepared from commercially available Pt catalyst supported on Vulcan XC-72R (Johnson Matthey, $10 \mathrm{wt} \% \mathrm{Pt}$, about $\left.120 \mathrm{~m}^{2} / \mathrm{Pt} \mathrm{g}\right)$. Pt/C $(1 \mathrm{~g})$ were dispersed in $25 \mathrm{ml}$ of deionized water and ultrasonically blended for 10 minutes. Appropriate amount of $0.1 \mathrm{M}$ solution of transition metal salts $\left(\mathrm{FeCl}_{2}, \mathrm{CuCl}_{2}\right)$ was added to this suspension. $\mathrm{Pt}: \mathrm{Cu}: \mathrm{Fe}$ atomic ratio was adjusted to $6: 1: 1\left(\mathrm{Pt}_{6} \mathrm{CuFe} / \mathrm{C}\right)$ and $2: 1: 1\left(\mathrm{Pt}_{2} \mathrm{CuFe} / \mathrm{C}\right)$ in resulting catalysts. Then the $\mathrm{pH}$ of the solution was adjusted to 8. After stirring, the suspension was filtered and dried at $100{ }^{\circ} \mathrm{C}$ for 2 hours. The quantitative analysis of the loaded metal amount was achieved with an ICP-AES. The dried catalysts were heated at $900{ }^{\circ} \mathrm{C}\left(\mathrm{Pt}_{6} \mathrm{CuFe} / \mathrm{C}\right)$ or $1100^{\circ} \mathrm{C}\left(\mathrm{Pt}_{2} \mathrm{CuFe} / \mathrm{C}\right)$ for 2.5 hours in reducing atmosphere and cooled to RT under flowing inert gas. The Pt $\mathrm{L}_{\mathbb{1 n}}$ edge EXAFS spectra were measured at the BL $10 \mathrm{~B}$ of the Photon Factory (Tsukuba). In order to determine the structural parameters, a curve fitting was performed for the first shell in the Fourier transform (FT). The electrochemical performance of the oxygen reduction was measured in a half cell apparatus. The reference electrode was a dynamic hydrogen electrode (DHE, $50 \mathrm{mV}$ lower than NHE) and the counter electrode was a large area platinum gauze. Polarization curve of oxygen reduction was obtained by potentiostatic method.

\section{RESULTS AND DISCUSSION}

Figure 1 shows the $\mathrm{k}^{3}$-weighted $\mathrm{Pt}_{\mathrm{III}}$ - edge EXAFS spectra of the $\mathrm{Pt}_{6} \mathrm{CuFe}_{\mathrm{f}}$ and $\mathrm{Pt}_{2} \mathrm{CuFe}$, in which the $\mathrm{k}$ range between $\sim 2.5$ $\AA^{-1}$ and $\sim 15.5 \AA^{-1}$ was Fourier transformed as shown in Figure 2. It is clearly seen that $\mathrm{FT}$ of $\mathrm{Pt}_{6} \mathrm{CuFe}$ is very similar to that of bulk platinum metal, whereas FT of $\mathrm{Pt}_{2} \mathrm{CuFe}$ shows a larger shoulder peak at the lower distance compared to $\mathrm{Pt}_{6} \mathrm{CuFe}$, indicating significant contributions of $\mathrm{Cu}$ and $\mathrm{Fe}$ as expected. But the consideration of only $\mathrm{Pt}-\mathrm{Pt}$ bonding pair in the curvefitting for $\mathrm{Pt}_{6} \mathrm{CuFe}$ could not give a reasonable result. Therefore, the three shell curve-fitting with the $\mathrm{Pt}-\mathrm{Pt}, \mathrm{Pt}-\mathrm{Cu}$, and $\mathrm{Pt}-\mathrm{Fe}$ contributions has been carried out for both compounds. Because the contributions of $\mathrm{Fe}$ and $\mathrm{Cu}$ to EXAFS oscillation cannot be distinguishable, we put the constraint that $\mathrm{Pt}-\mathrm{Cu}$ distance is shorter than $\mathrm{Pt}-\mathrm{Fe}$ one from the consideration of ionic radii. The best-fitted spectra for both compounds are shown in Figure 2, and the resulting structural parameters are given in Tables 2. The fitted Pt-Pt distances for both compounds are similar to each other, and slightly shortened compared to that ( $2.772 \AA)$ of the bulk Pt metal. These reduced Pt-Pt bond distances well reflect the reduced unit cell parameters estimated by XRD. In addition, the $\mathrm{Pt}-\mathrm{Cu}$ and $\mathrm{Pt}-\mathrm{Fe}$ distances decrease as the relative amounts of $\mathrm{Cu}$ and $\mathrm{Fe}$ increase. The observed total coordination numbers (C.N.) of $\mathrm{Pt}-(\mathrm{Pt} / \mathrm{Cu} / \mathrm{Fe})$ pair for both compounds are also similar to the coordination of twelve for $\mathrm{Pt}$ metal. It has been well 


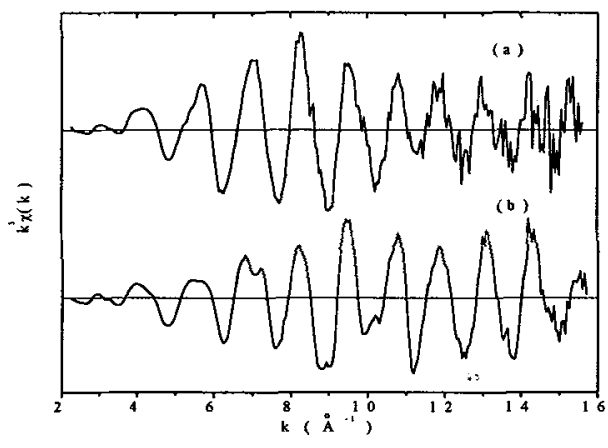

Figure 1: The $\mathrm{k}^{3}$-weighted EXAFS spectra at the $\mathrm{Pt} \mathrm{L}_{\mathrm{II}}$ edge for $\mathrm{Pt}_{2} \mathrm{CuFe} / \mathrm{C}$ (a) and $\mathrm{Pt}_{6} \mathrm{CuFe} / \mathrm{C}(\mathrm{b})$.

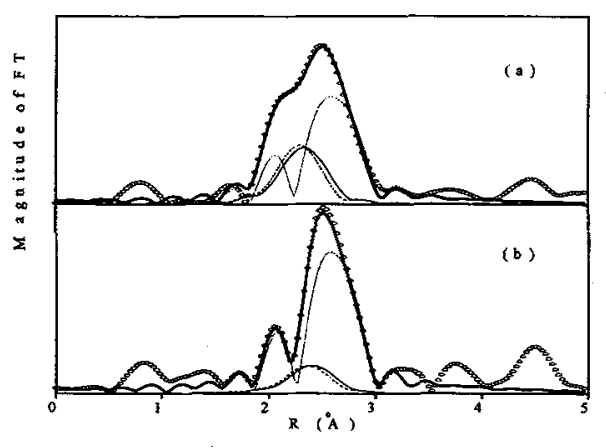

Figure 2: The experimental (o) and best-fitted $(-)$ FTs for $\mathrm{Pt}_{2} \mathrm{CuFe} / \mathrm{C}$ (a) and $\mathrm{Pt}_{6} \mathrm{CuFe} / \mathrm{C}$ (b). The contributions of Pt-Pt (--), $\mathrm{Pt}-\mathrm{Fe}(--)$, and Pt-Cu (-) pairs to the best-fitted FT are shown.

accepted that EXAFS analysis for material of small particle size might induce the smaller C.N. due to the enhanced surface areas than those expected for bulk material.[2] In this regard, the resulting C.N. suggests that particle sizes for both catalysts are not so small, even though considering that experimental errors for C.N. is generally $\pm 20 \%$. It is of great interest the ratio of C.N. is $\mathrm{Pt}: \mathrm{Cu}: \mathrm{Fe}=73: 13: 14$ for $\mathrm{Pt}_{6} \mathrm{CuFe} / \mathrm{C}$ and $\mathrm{Pt}: \mathrm{Cu}: \mathrm{Fe}=55: 21: 24$ for $\mathrm{Pt}_{2} \mathrm{CuFe} / \mathrm{C}$, which are consistent with the compositional ratio. Such a fact suggests that $\mathrm{Cu}$ or $\mathrm{Fe}$ is well penetrated into the interior of the Pt lattice giving rise to the formation of homogeneous and long range ordered alloys, irrespective of the compositional ratio. Both compounds do not display the peak at low distance due to $\mathrm{Pt}-\mathrm{C}$ distances, indicating that these materials are resistant to carbon deposition and oxidation.

The eletrocatalytic activities for oxygen reduction (Table 2) are measured to see the alloying effect under operating conditions of phosphoric acid fuel cell. The alloy catalysts show enhanced mass activity, which means a higher current density normalized to the weight of $\mathrm{Pt}$ in the tested electrode. To see the net enhancement exhibited by alloy catalysts, it is reasonable to compare specific activity or real activity per unit surface area because metal surface area may be changed upon heating. As shown in Table 2, the alloy catalysts exhibit higher specific activities than the Pt alone catalyst by about $50 \%$. We suppose that the enhanced catalytic activity obtained in this study is not solely due to the roughness effect [1], as the kinetics of oxygen reduction is also influenced by the bond strength or coverage of oxygen molecules on the surface of the electrocatalyst [3]. Since the absorption properties of $\mathrm{Pt}$ should be changed by forming alloy with $\mathrm{Cu}$ and $\mathrm{Fe}$, the enhanced activity of the alloy catalysts seems to be related to this changed property in addition to the roughness effect.

Table 1: Structural parameters obtained by curve-fittings of $P t L_{I I I}-$ edge EXAFS spectra for $\mathrm{Pt}_{6} \mathrm{CuFe} / \mathrm{C}$ and $\mathrm{Pt}_{2} \mathrm{CuFe} / \mathrm{C}$.

\begin{tabular}{|c|c|c|c|c|c|}
\hline compounds & scatterer & C.N. ${ }^{2}$ & $\mathrm{R}(\AA)^{\mathbf{n}}$ & $\sigma^{2}\left(\AA^{2}\right)^{2}$ & $\Delta \mathrm{E}_{0}(\mathrm{eV})^{\mathrm{a}}$ \\
\hline \multirow[t]{3}{*}{$\mathrm{Pt}_{6} \mathrm{CuFe}$} & $\mathrm{Pt}$ & 8.0 & $2.71_{4}$ & 0.0055 & 5.9 \\
\hline & $\mathbf{C u}$ & 1.4 & 2.699 & 0.0073 & \\
\hline & $\mathrm{Fe}$ & 1.5 & $2.70_{5}$ & 0.0078 & \\
\hline \multirow[t]{3}{*}{$\mathrm{Pt}_{2} \mathrm{CuFe}$} & $\mathrm{Pt}$ & 6.7 & 2.719 & 0.0054 & 4.9 \\
\hline & $\mathrm{Cu}$ & 2.5 & 2.625 & 0.0065 & \\
\hline & $\mathrm{Fe}$ & 2.9 & $2.63_{2}$ & 0.0077 & \\
\hline
\end{tabular}

C.N. is the number of scatterers. $R$ is the metal-scatterer distance. $\sigma^{2}$ is a mean square deviation in $\mathrm{R} . \Delta \mathrm{E}_{0}$ is the shift in $\mathrm{E}_{0}$ for the theoretical scattering function.
Table 2: Electrochemical activity for oxygen reduction reaction.

\begin{tabular}{lccc}
\hline compounds & $\begin{array}{c}\text { mass activity } \\
\left(\mathrm{A} \mathrm{g}^{-1}\right)\end{array}$ & $\begin{array}{c}\mathrm{ECMSA} \\
\left(\mathrm{m}^{2} \mathrm{~g}^{-1}\right)\end{array}$ & $\begin{array}{c}\text { specific activity } \\
\left(\mu \mathrm{A} \mathrm{cm} \mathrm{cm}^{-2}\right)\end{array}$ \\
\hline $\mathrm{Pt}_{6} \mathrm{CuFe}$ & 86.1 & 52.9 & 163 \\
$\mathrm{Pt}_{2} \mathrm{CuFe}$ & 69.1 & 38.5 & 179 \\
$\mathrm{Pt}^{\mathrm{d}} \mathrm{C}^{\mathrm{d}}$ & 58.6 & 53.2 & 110 \\
\hline Measured at $0.9 \mathrm{~V}$ (vs. DHE) in $100 \% \mathrm{H}_{3} \mathrm{PO}_{4}$ at $200^{\circ} \mathrm{C}$. \\
Electrochemical metal surface area measured by cyclic \\
voltammetry at the scan rate of $10 \mathrm{mVs}^{-1}$ in $1 \mathrm{M} \mathrm{H}_{2} \mathrm{SO}_{4}$ at $20^{\circ} \mathrm{C}$. \\
c The specific activity is obtained by dividing the mass activity \\
with specific metal surface area measured electrochemically. \\
'Pt alone catalyst heat-treated at $900^{\circ} \mathrm{C}$ for $2.5 \mathrm{hr}$.
\end{tabular}

\section{Conclusion}

The structures of Pt-Cu-Fe ternary alloy electrocatalysts elucidated by the $\mathrm{Pt} \mathrm{L}_{\mathrm{m}}$-edge EXAFS analyses suggest that both catalysts are homogeneous and consist of relatively large particles. The reduced Pt-Pt distance upon the formation of alloy indicates that alloying effect gives an influence on the local structures, consequently resulting in variation of the electronic structures of constituent metal atoms. According to the electrochemical test, these alloy exhibit enhanced catalytic activity towards oxygen reduction reaction.

\section{Acknowledgments}

The authors are grateful to Prof. M. Nomura (PF, Japan) for his help in obtaining XANES spectra and to KOSEF for the financial support through the Center for Molecular Catalysis (CMC).

\section{References}

[1] Daube K., Paffett M., Gottesfeld S., Campbell C., J. Vac. Sci. Technol. A 4 (1986) 1617.

[2] Greegor R. B., Lytle F. W., J. Catal. 63 (1980) 476.

[3] Kinoshita K., Electrochemical Oxygen Technology (Wiley-Interscience Pub., New York, 1992 ) p50. 